\begin{tabular}{|l|l|l||}
\hline \multicolumn{2}{|c|}{ PublisherInfo } \\
\hline \hline PublisherName & $:$ & BioMed Central \\
\hline \hline PublisherLocation & $:$ & London \\
\hline \hline PublisherImprintName & $:$ & BioMed Central \\
\hline \hline
\end{tabular}

\title{
Recombinant Vaccinia infects lab worker
}

\begin{tabular}{|l|l|l||}
\hline \multicolumn{2}{|c|}{ ArticleInfo } \\
\hline \hline ArticleID & $:$ & 4736 \\
\hline \hline ArticleDOI & $:$ & $10.1186 /$ gb-spotlight-20030401-01 \\
\hline \hline ArticleCitationID & $:$ & spotlight-20030401-01 \\
\hline \hline ArticleSequenceNumber & $:$ & 88 \\
\hline \hline ArticleCategory & $:$ & Research news \\
\hline ArticleFirstPage & $:$ & 1 \\
\hline \hline ArticleLastPage & $:$ & 2 \\
\hline \hline & & RegistrationDate : 2003-4-1 \\
\hline ArticleHistory & $:$ & OnlineDate \\
\hline \hline ArticleCopyright & $:$ & BioMed Central Ltd2003-1 \\
\hline \hline ArticleGrants & $:$ & \\
\hline \hline ArticleContext & $:$ & 130594411 \\
\hline \hline
\end{tabular}




\section{Ricki Lewis}

Email: rickilewis@nasw.org

Reinstating smallpox vaccination programs to protect the public against bioterrorism is currently a topic of considerable debate. Some countries additionally recommend the practice for laboratory workers who encounter Vaccinia, the cowpox virus that is the basis of the vaccine and which is used as a cassette in other vaccines. Acquiring active infection by working with Vaccinia has been assumed to be unlikely, but in the March 2003 Journal of Investigative Dermatology, Martin Mempel and colleagues at the Technical University, Munich, Germany, describe a 40-year-old Caucasian male who developed pox-like lesions on a finger on each hand after working with Vaccinia (The Journal of Investigative Dermatology, 120:356-258, March, 2003).

Mempel et al. recognized vesicles that gradually turned into raised, dark nodules as similar to those that develop during cowpox infection. The patient had no contact with farm animals, but had worked with lab strains of Vaccinia containing human genes - in particular an inactivated form of the human gene for cytohesin-1, which could impair the local immune response in the skin by interfering with leukocyte adhesion. The man had been vaccinated against smallpox at 1 year old and again when 10 years old.

Microbiological and genetic tests confirmed that recombinant Vaccinia caused the vesicles. Mempel et al. speculate that vaccination may have prevented a more severe reaction - suggesting that US workers born after 1972, when vaccination ceased, could respond with a more severe reaction.

"The scientist was working with very high concentrations of recombinant Vaccinia virus, which contained an immunomodulating insert which could possibly have changed the virulence," senior author of the paper Heidelore Hofmann told us.

The particular strain is called Western Reserve, and this is the first report of a lesion from such a laboratory strain without an obvious wound. Hofmann echoed the Centers for Disease Control's recommendation: "Vaccinia vaccination should be mandatory for laboratory workers and medical staff handling Vaccinia virus." European nations do not have specific recommendations, she added.

\section{References}

1. Centers for Disease Control and Prevention, [http://www.bt.cdc.gov/agent/smallpox/index.asp]

2. Brickley P: "National anthrax vaccination urged," The Scientist, October 22, 2002., [http://www.thescientist.com/news/20021022/07/]

3. The Journal of Investigative Dermatology, [http://www.jidonline.org/]

4. Technical University, Munich, [http://www.tu-muenchen.de/jshpchooser.tupl]

This PDF file was created after publication. 